\title{
Measurement of Effectiveness of Zinc with and without FYM on Protein Production by Pearl Millet-Wheat Sequence
}

\author{
Anand Pathak ${ }^{1 *}$, Apoorv Tiwari ${ }^{2}$ Akhil Gupta ${ }^{3}$ and Vipin Kumar ${ }^{1}$ \\ ${ }^{1}$ Department of Agricultural Chemistry and Soil Sciences, Raja Balwant Singh College, \\ Bichpuri, Agra, Uttar Pradesh, India \\ ${ }^{2}$ Department of Molecular Biology and Genetic Engineering, CBSH, GBPUA\&T, \\ Pantnagar, Uttarakhand, India \\ ${ }^{3}$ Department of Genetics and Plant Breeding, College of Agriculture, GBPUA\&T, \\ Pantnagar, Uttarakhand, India \\ *Corresponding author
}

A B S T R A C T

Pearl millet-wheat cropping system is important cropping system of northern India and is traditionally a component of the dry land system, usually grown in soils with depleted in

Keywords

FYM, Zn,

Nutrients, Millet, Wheat, Fertilizers.

Article Info

Accepted:

26 August 2017

Available Online:

10 September 2017 sandy areas, where deficiency of $\mathrm{Zn}$ is a common occurrence. In the present study it was found that the higher level of $\mathrm{Zn}(10 \mathrm{~kg} / \mathrm{ha})$ did not improve the protein yield over $7.5 \mathrm{~kg}$ $\mathrm{Zn} / \mathrm{ha}$ in both crop seasons. This may be attributed to lower grain production at $10 \mathrm{~kg}$ $\mathrm{Zn} /$ ha treatment. The addition of FYM also improved the protein yield over control in both crop seasons. There was a significant increase in protein yield with combined application of FYM and zinc levels and maximum yield was recorded with $7.5 \mathrm{~kg} \mathrm{Zn}+5$ ton FYM/ha treatment in both crop seasons. Application of 5 ton FYM/ha also improved protein content in grain and stover of pearl millet significantly over control. When the combined FYM and $\mathrm{Zn}$ were used together, the resulted in higher value of $\mathrm{Zn}$ content in grain and stove was observed. The maximum values of $\mathrm{Zn}$ content in grain and stover were noted under 5 ton FYM/ha $+10 \mathrm{~kg} \mathrm{Zn/ha} \mathrm{in} \mathrm{both} \mathrm{crop} \mathrm{seasons.} \mathrm{The} \mathrm{residual} \mathrm{effect} \mathrm{of} \mathrm{FYM} \mathrm{on}$ zinc uptake by wheat grain and straw was significant over control in both crop seasons. The results, thus, indicate the beneficial effect of combined used of $\mathrm{Zn}$ levels with FYM.

\section{Introduction}

Zn plays an important role in the stabilization of structural orientation of the membrane proteins due to its preferential binding of sulphdryl group. Zinc influences translocation and transport of $\mathrm{P}$ in plants. Under $\mathrm{Zn}$ deficiency, excessive translocation of $\mathrm{P}$ occurs resulting in $\mathrm{P}$ toxicity. Zinc is not translocated within the plant. So symptoms first appear on the younger leaves and other plant parts. Common symptoms of zinc deficiency, which generally occurs, are stunted growth poor tillering, development of light green yellowing bleached spots, chlorotic bands on either side of the midrib in the plants. Zinc was recently assumed great importance in crop production as it plays a significant role in oxidation and reduction process. Qualitative and quantitative importance of zinc application to several crops has been well established in literature 
(Dahiya et al., 1987). In many parts of India, zinc as a plant nutrient now stands third in importance next to nitrogen and phosphorous. The deficiency of zinc under semi-arid climate has emerged as a serious limitation to crop production. Zinc deficiency is being widely experienced in the light textured soils. The soils of Agra region vary in texture from sandy to clay loam, alkaline in nature, low in organic carbon content and generally quite low in fertility status (Singh et al., 2004). Zinc deficiency to the extent of 80 percent has been observed in the intensively cropped alluvial soil of Uttar Pradesh (Tiwari et al., 1995), where pearl millet-wheat cropping sequences predominate.

The use of organic manures had a prestigious position with farmers in the past, but subsequently the introduction of high analysis fertilizers cast a shadow on their spread. (Verma et al., 2005) It is well known that addition of organic manures has shown considerable increase in crop yield and exert significant influence on physical, chemical and biological properties of soil FYM has to be used to prevent the decline in the content of organic matter and nitrogen by contiguous cropping (Sharma, et al., 1990). The application of FYM is found to influence the pore space, permeability to water and air, structure formation and some other physical properties. It reduces the soil erosion. Farm yard manure increases the humus content of soils at least temporarily and consequently the water holding capacity of sandy soils is increased and the drainage of clayey soils is improved. FYM provides food for soil microorganisms. Addition of organic matter may help in increasing nutrients availability both from applied and native sources. But its use alone is not sufficient to meet the requirement of nutrients. Therefore, use of both organic manures and chemical fertilizers in appropriate proportion assumes special significance as complementary and supplementary to each other in crop production. The information on the behaviour of organic matter and zinc in light textured soil is limiting. Hence, the present study was undertaken with a view to study the integrated effect of FYM and zinc on pearl millet and wheat productivity.

Due to rising cost of chemical fertilizers, use of alternative sources like crop residues, farm wastes, and FYM is being advocated. Integrated use of organic and inorganic fertilizers has been found to be promising not only for maintaining higher productivity, but also maximum stability in terms of crop yield. The profitability of zinc application in conjunction with FYM could be higher, if the carry-over (residual) benefits of a single application to succeeding crops are taken into account. The response of soil applied zinc and FYM could be more correctly assessed on cropping system basis rather than on a single crop basis. No information is available for the optimum dose and residual effect of zinc fertilizer application for pearl millet-wheat system practiced in south western plain, zone of Uttar Pradesh. The present investigation was undertaken to assess the effect of direct and residual availability of $\mathrm{Zn}$ on pearl millet and wheat crops.

Pearl millet-wheat sequence is predominant in north-western plain zone and central zone of India. Even with the application of recommended dose of fertilizers yield potential of this sequence (Cereal-cereal) has reached to plateau because of deterioration in soil health. In sustainable crop production, organic manuring plays an important role. The results of a large number of experiments on manures and fertilizers conducted in the country and aboard reveal that neither the chemical fertilizer alone nor the organic sources exclusively can achieve the production sustainability of soils as well as crops under highly intensive cropping system. 
Therefore, it becomes necessary to know the suitable combination of zinc fertilizers with organic manures for profitable crop production in cereal based cropping system.

\section{Materials and Methods}

The investigation entitled "Direct and residual effect of zinc with and without FYM in pearl millet-wheat cropping system" was carried out at research farm R.B.S. College, Bichpuri, Agra during kharif and rabi seasons of 200809 and 2009-10 to evaluate the effect of zinc with and without FYM on pearl millet-wheat cropping system. The details of the materials used and procedures employed in these studies are described in the ensuring text.

\section{Geology and climate}

The area under investigation falls in the IndoGangetic plains. The soils in this tract owe their origin to the alluvium deposited by the two great rivers, the Ganga and the Yamuna, belonging to Pleistocene age. The alluviums can be divided into two sub-groups:

(i) Old (Pleistocene) alluvium known as Bangar and (ii) recent alluvium known as khaddar. The boundary between two alluviums is not sharp the old alluviums usually occupy terrace like position and tend to be silty sands.

The climate of Agra district on the whole is hot and dry. The mean annual rainfall for this district is around $65 \mathrm{~cm}$ of which nearly 90 per cent is received during the rainy season i.e. from June to September. However, a few showers commonly occur during winter season and sometimes fog and frost are also experienced. Desiccating winds and scorching heat characterize summers.

The soils in this district have been formed from the alluvium laid down by the two great rivers-the Ganga and the Yamuna. The soils are of great depth and are not often fully mature in development. They are essentially basic in character; usually light textured and highly productive.

\section{Experimental site}

The experiment was carried out in plot B-12b of the Raja Balwant Singh College, Research Farm, Bichpuri (Agra) during both the years. The field had received no zinc in the past history of cropping and management. The site of this experiment is situated about $11 \mathrm{kms}$ away from Agra city and located at AgraBharatpur road.

\section{Experimental details}

Field experiments for two consecutive years were carried out with following treatments:

Control

$2.5 \mathrm{~kg} \mathrm{Zn/ha}$

$5 \mathrm{~kg} \mathrm{Zn} / \mathrm{ha}$

$7.5 \mathrm{~kg} \mathrm{Zn} / \mathrm{ha}$

$10 \mathrm{~kg} \mathrm{Zn/ha}$

$5 \mathrm{t} \mathrm{FYM/ha}$

$2.5 \mathrm{~kg} \mathrm{Zn}+5 \mathrm{t} \mathrm{FYM} / \mathrm{ha}$

$5 \mathrm{~kg} \mathrm{Zn}+5 \mathrm{t} \mathrm{FYM} / \mathrm{ha}$

$7.5 \mathrm{~kg} \mathrm{Zn}+5 \mathrm{t} \mathrm{FYM/ha}$

Crop: Pearl millet-wheat crop sequence

Replication: 4

Design: RBD

\section{Preparation of the experimental field and fertilizer applications}

The experimental field was prepared by a deep tractor ploughing and disking and finally laid out in to plots leaving irrigation channels and bunds in between the treatments.

Nitrogen, phosphorus and potassium were applied through urea, di-ammonium phosphate and muriate of potash, respectively. Recommended doses of NPK for pearl millet 
$(120,60,40 \mathrm{~kg} / \mathrm{ha})$ and wheat $(150,60$ and 40 $\mathrm{kg} / \mathrm{ha}$ ) were applied at the time of sowing. Zinc was applied through zinc sulphate as per treatments at the time of sowing in pearl millet only. Well decomposed FYM was applied as per treatments 15 days before sowing of both the crops.

\section{Seed and sowing of pearl millet and wheat}

The seeds of pearl millet were sown in lines at $30 \mathrm{~cm}$ apart, using the seed rate of $5 \mathrm{~kg} / \mathrm{ha}$ in the month of July in both years. The lines were opened by pointed spade by human labour. After sowing, planking was done to cover the seed.

The seeds of wheat were sowing in lines at 20 $\mathrm{cm}$ apart, using a uniform seed rate of 125 $\mathrm{kg} / \mathrm{ha}$ in the month of November during both the years. The lines were opened by pointed spade by human labour. After sowing, planking was done to cover the seed. The crops were irrigated at the proper time as judged by the appearance of soil and the crop. The source of irrigation water was canal. At harvest, the grain and straw/stover yields of the crops were recorded.

\section{Chemical analysis}

The grain and straw samples were dried in sun followed by in oven at $70^{\circ} \mathrm{C}$ for 5 hours. They were then ground in a Wiley's mill and stored in wide mouth glass stoppered bottles with proper labeling. The following determinations were made from the wellprepared plant materials.

\section{Protein}

From the nitrogen content values, the protein percentage in plant was calculated according to formula mentioned below:

Protein percentage $=\mathrm{N}$ content $(\%) \times 6.25$

\section{Zinc}

Zinc in the di-acid $\left(\mathrm{HNO}_{3}\right.$ and $\left.\mathrm{HClO}_{4}\right)$ extract of the plant material was determined on an atomic absorption spectrophotometer.

\section{Uptake studies}

The uptake of nitrogen, phosphorus, potassium, sulphur and zinc by the crops was computed by multiplying contents of the elements with the yield data.

\section{Chemical analysis of soil samples}

Soils samples collected after harvest of both the crops were analysed for their properties.

\section{Soil pH}

It was measured in 1:2.5 soil-water suspensions by Beckna model ' $\mathrm{H}$ ' $\mathrm{pH}$ meter using glass electrode.

\section{Available zinc}

The soil was shaken with a mixture of 0.005 $M$ DTPA, $0.01 \mathrm{M} \mathrm{CaCl}{ }_{2}$ and $0.1 \mathrm{M}$ triethanolamine ( $\mathrm{pH}$ 7.3) as suggested by Lindsay and Norvell (1978).

The aliquot was filtered through Whatmann No. 42 filter paper. The zinc contents in the prepared extract were determined in an atomic absorption spectrophotometer.

\section{Results and Discussion}

The results of the present investigations were obtained for yield, quality parameters of the crops, uptake studies and soil fertility are presented and discussed are as follows

Nutrient Uptake Analysis

Pearl millet

Qualitative studies 


\section{Protein}

Data on protein content as affected by various treatments are presented in figures 1 and 2 . A study of the data indicates that the application of zinc significantly increased the protein percentage in pearl millet grain and stover over control. The protein content in grain and straw increased from 11.12 to 11.56 per cent with $10 \mathrm{~kg}$ zinc/ha level in 2008. The corresponding increase in protein content in grain was from 11.25 to 11.68 per cent in 2009. The increase in protein content due to $\mathrm{Zn}$ addition might be attributed to its involvement in nitrogen metabolism of plants. Application of $5 \mathrm{t} \mathrm{FYM/ha}$ also improved protein content in grain and stover of pearl millet significantly over control. The combined application of FYM and levels of zinc further improved the protein percentage in the crop. From quality point of view, application of $5 \mathrm{t} \mathrm{FYM}+7.5 \mathrm{~kg} \mathrm{Zn} / \mathrm{ha}$ treatment appears to be the best. (Subbiah et al., 1956). This may be due to the fact that the plants accumulated more nitrogen with this treatment and ultimately showing more protein per cent. Thus the combined application of $\mathrm{Zn}$ and FYM proved more beneficial in respect of protein percentage in pearl millet grain.

\section{Protein production}

A further study of the data (Fig. 3) indicated that in general, the minimum protein yield of pearl millet grain was recorded under control in both crop seasons. This may be attributed to lower yield of pearl millet grain. Application of zinc improved the protein yield of pearl millet grain in both crop seasons. The protein yield increased from $117.92 \mathrm{~kg} / \mathrm{ha}$ at control to $224.14 \mathrm{~kg} / \mathrm{ha}$ with $7.5 \mathrm{~kg} \mathrm{Zn} / \mathrm{ha}$ in first year. The corresponding increase in protein yield was from 190.12 to $236.05 \mathrm{~kg} / \mathrm{ha}$ in 20096 . This improvement in protein yield may be attributed to increased grain production and improvement in protein content with $\mathrm{Zn}$ application. Gangwar and Singh (1988) also reported similar results. The higher level of $\mathrm{Zn}(10 \mathrm{~kg} / \mathrm{ha})$ did not improve the protein yield over $7.5 \mathrm{~kg} \mathrm{Zn} / \mathrm{ha}$ in both crop seasons. This may be attributed to lower grain production at $10 \mathrm{~kg} \mathrm{Zn} / \mathrm{ha}$ treatment. The addition of FYM also improved the protein yield over control in both crop seasons. There was a significant increase in protein yield with combined application of FYM and zinc levels and maximum yield was recorded with $7.5 \mathrm{~kg} \mathrm{Zn}$ $+5 \mathrm{t} \mathrm{FYM} / \mathrm{ha}$ treatment in both crop seasons.

\section{Zinc}

Data on content and uptake of $\mathrm{Zn}$ by pear millet crop are presented in table 1. A study of the data reveals that the application of zinc increased its content in grain and stover significantly over control. This increase in zinc content in grain and stover may be attributed to increased availability of zinc as a result of its addition. The results obtained in the present study are in agreement with those of Malewar et al., (2001).

Application of $5 \mathrm{t} \mathrm{FYM/ha,} \mathrm{also} \mathrm{increased} \mathrm{the}$ content of zinc in pearl millet crop significantly over control in both crop seasons. The combined use of FYM and $\mathrm{Zn}$ resulted in higher value of $\mathrm{Zn}$ content in grain and stove. The maximum values of $\mathrm{Zn}$ content in grain and stover were noted under $5 \mathrm{t} \mathrm{FYM} / \mathrm{ha}+10 \mathrm{~kg} \mathrm{Zn} / \mathrm{ha}$ in both crop seasons. Such increase in $\mathrm{Zn}$ content due to $\mathrm{Zn}+\mathrm{FYM}$ use has been reported to be associated with the release of $\mathrm{Zn}$ during the course of microbial decomposition.

A perusal of the data (Table 1) indicates that the application of zinc increased its uptake significantly over control in both crop seasons. The higher values of $\mathrm{Zn}$ uptake were noted at $10 \mathrm{~kg} \mathrm{Zn} / \mathrm{ha}$. 
Table.1 Effect of various treatments on content and uptake of zinc by Pearl millet grain and stover

\begin{tabular}{lllllllll} 
& Zn & & \multicolumn{5}{c}{ Zn uptake (kg/ha) } \\
Treatment & $\begin{array}{l}\text { Grain } \\
\text { Grain }\end{array}$ & \multicolumn{3}{c}{ Stover } & \multicolumn{5}{c}{ Stover } \\
& $\mathbf{2 0 0 8}$ & $\mathbf{2 0 0 9}$ & $\mathbf{2 0 0 8}$ & $\mathbf{2 0 0 9}$ & $\mathbf{2 0 0 8}$ & $\mathbf{2 0 0 9}$ & $\mathbf{2 0 0 8}$ & $\mathbf{2 0 0 9}$ \\
Control & 22.4 & 23.0 & 30.2 & 30.7 & 35.8 & 38.8 & 203.9 & 215.0 \\
$2.5 \mathrm{~kg} \mathrm{Zn} / \mathrm{ha}$ & 26.0 & 26.6 & 33.4 & 34.0 & 44.8 & 48.0 & 237.3 & 250.9 \\
$5 \mathrm{~kg} \mathrm{Zn} / \mathrm{ha}$ & 29.2 & 29.5 & 35.8 & 36.7 & 55.7 & 58.5 & 280.0 & 293.8 \\
$7.5 \mathrm{~kg} \mathrm{Zn} / \mathrm{ha}$ & 32.0 & 32.7 & 39.5 & 40.4 & 662.7 & 66.7 & 312.6 & 327.8 \\
$10 \mathrm{~kg} \mathrm{Zn} / \mathrm{ha}$ & 33.7 & 33.5 & 40.7 & 41.6 & 63.1 & 64.8 & 315.8 & 330.4 \\
$5 \mathrm{t} \mathrm{FYM} / \mathrm{ha}$ & 28.5 & 29.1 & 34.6 & 35.2 & 53.1 & 56.1 & 265.5 & 279.9 \\
$2.5 \mathrm{~kg} \mathrm{Zn}+5 \mathrm{t} \mathrm{FYM} / \mathrm{ha}$ & 29.8 & 30.2 & 36.0 & 36.7 & 59.7 & 62.7 & 296.0 & 308.2 \\
$5 \mathrm{~kg} \mathrm{Zn}+5 \mathrm{t} \mathrm{FYM/ha}$ & 32.0 & 32.7 & 38.2 & 38.8 & 69.8 & 73.6 & 322.9 & 335.7 \\
$7.5 \mathrm{~kg} \mathrm{Zn}+5 \mathrm{t} \mathrm{FYM/ha}$ & 33.4 & 33.6 & 40.0 & 41.0 & 75.6 & 78.0 & 344.3 & 357.6 \\
$\mathrm{SEm} \pm$ & 1.52 & 1.48 & 1.57 & 1.61 & 3.01 & 2.95 & 7.81 & 8.02 \\
$\mathrm{CD}(\mathrm{P}=0.05)$ & 4.44 & 4.32 & 4.58 & 4.70 & 8.78 & 8.61 & 22.80 & 23.41
\end{tabular}

Table.2 Residual effect of various treatments on zinc content and uptake by Wheat grain and straw

\begin{tabular}{|c|c|c|c|c|c|c|c|c|}
\hline \multirow[t]{3}{*}{ Treatment } & \multicolumn{4}{|c|}{ Zinc continent $(\%)$} & \multicolumn{4}{|c|}{ Zinc uptake (kg/ha) } \\
\hline & \multicolumn{2}{|c|}{ Grain } & \multicolumn{2}{|c|}{ Straw } & \multicolumn{2}{|c|}{ Grain } & \multicolumn{2}{|c|}{ Straw } \\
\hline & 2008 & 2009 & 2008 & 2009 & 2008 & 2009 & 2008 & 2009 \\
\hline Control & 19.8 & 20.2 & 26.0 & 26.4 & 88.5 & 92.0 & 145.3 & 150.4 \\
\hline $2.5 \mathrm{~kg} \mathrm{Zn} / \mathrm{ha}$ & 23.0 & 23.5 & 29.4 & 29.8 & 106.9 & 110.8 & 169.5 & 174.3 \\
\hline $5 \mathrm{~kg} \mathrm{Zn/ha}$ & 25.8 & 26.4 & 31.7 & 32.3 & 123.9 & 128.9 & 192.0 & 199.1 \\
\hline $7.5 \mathrm{~kg} \mathrm{Zn} / \mathrm{ha}$ & 28.0 & 28.6 & 35.1 & 35.8 & 139.0 & 142.7 & 215.3 & 232.2 \\
\hline $10 \mathrm{~kg} \mathrm{Zn/ha}$ & 29.5 & 30.0 & 36.5 & 37.0 & 144.5 & 148.4 & 222.0 & 228.8 \\
\hline $5 \mathrm{t}$ FYM/ha & 24.5 & 25.2 & 30.5 & 31.0 & 118.8 & 124.2 & 186.5 & 193.1 \\
\hline $2.5 \mathrm{~kg} \mathrm{Zn}+5 \mathrm{t}$ FYM $/ \mathrm{ha}$ & 26.0 & 26.6 & 32.1 & 32.7 & 130.0 & 137.0 & 202.8 & 211.9 \\
\hline $5 \mathrm{~kg} \mathrm{Zn}+5 \mathrm{t} \mathrm{FYM} / \mathrm{ha}$ & 28.4 & 29.2 & 34.5 & 35.0 & 143.7 & 151.8 & 220.1 & 229.3 \\
\hline $7.5 \mathrm{~kg} \mathrm{Zn}+5 \mathrm{t} \mathrm{FYM} / \mathrm{ha}$ & 29.7 & 30.1 & 36.7 & 37.2 & 151.7 & 158.1 & 236.1 & 246.3 \\
\hline SEm & 1.25 & 1.31 & 1.47 & 1.51 & 2.96 & 3.05 & 3.62 & 3.47 \\
\hline $\mathrm{CD}(\mathrm{P}=0.05)$ & 3.65 & 3.82 & 4.29 & 4.41 & 8.64 & 8.90 & 10.05 & 10.13 \\
\hline
\end{tabular}

Fig.1 Effect of various treatments on grain and stover yield in pearl millet in different years (2008-2009)

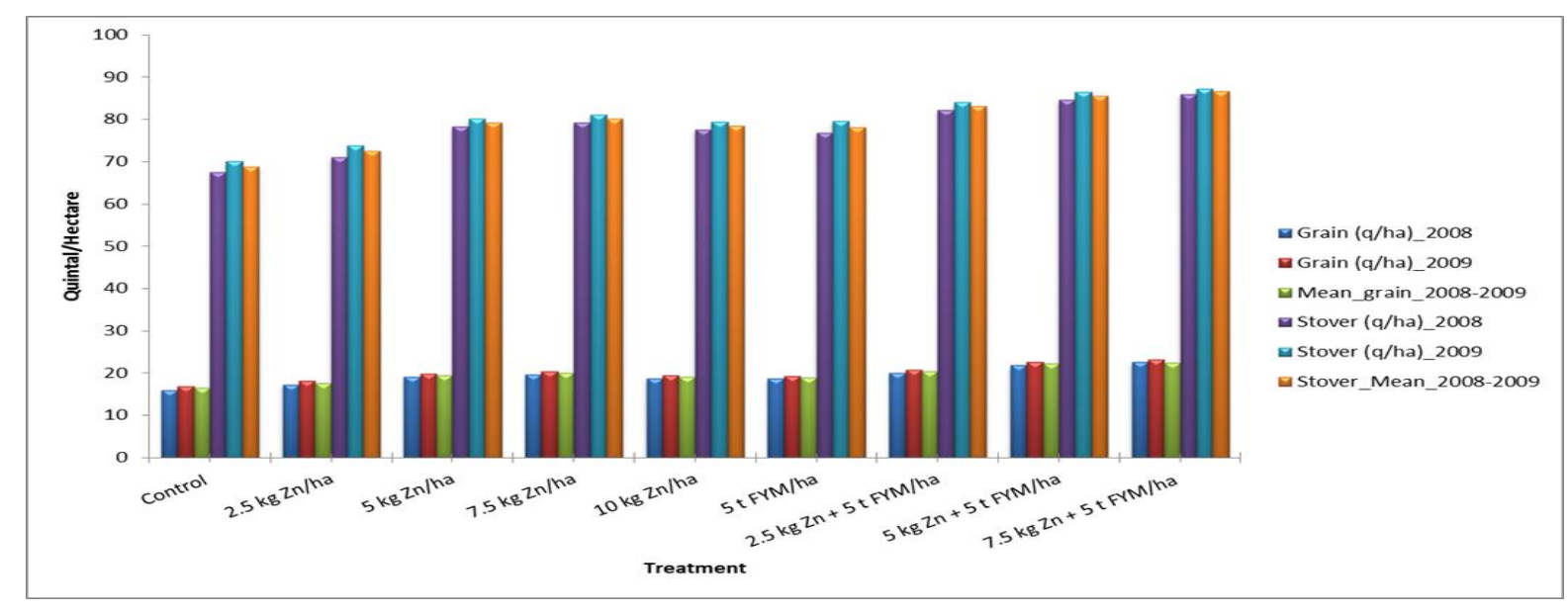


Fig.2 Effect of various treatments on protein content in pearl millet

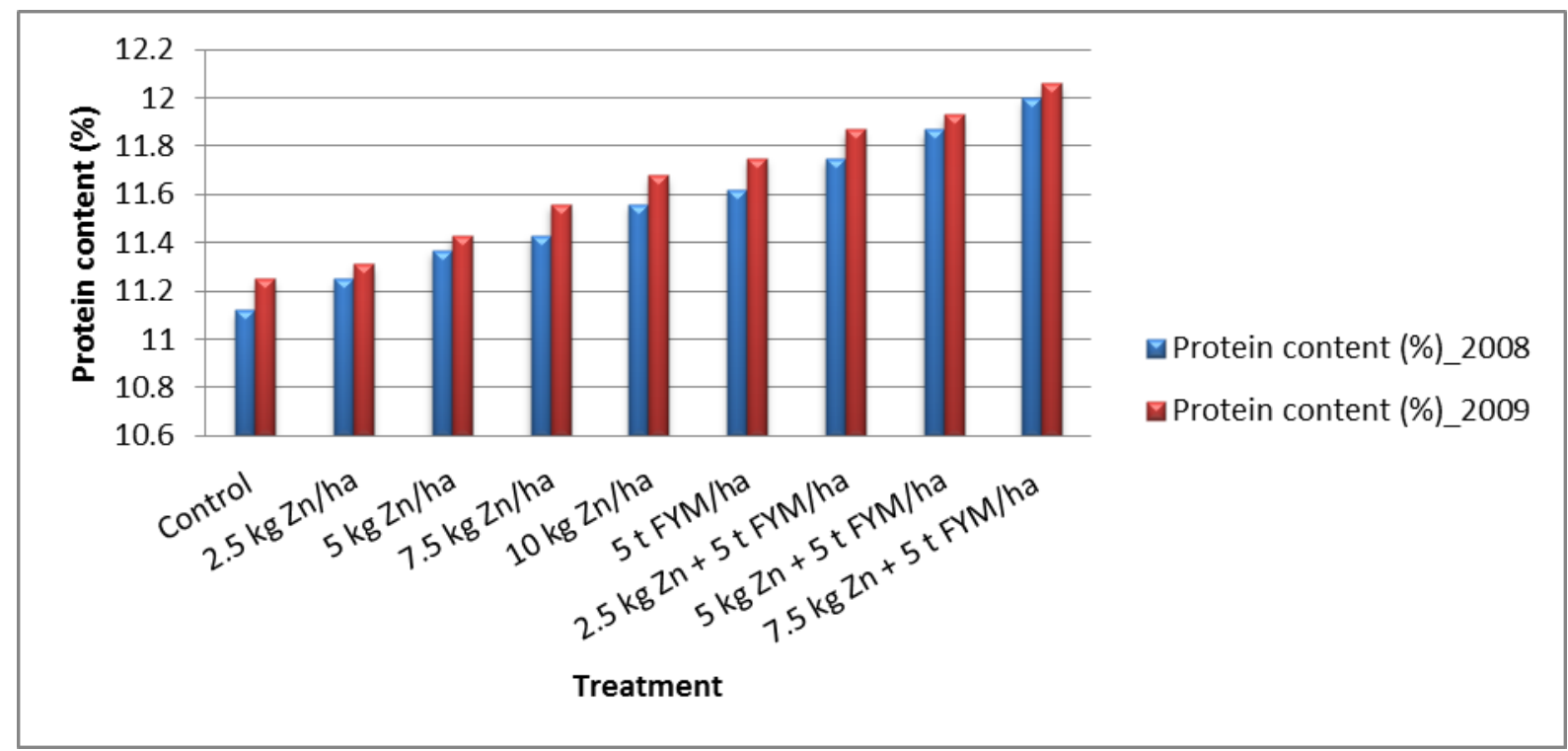

Fig.3 Effect of various treatments on protein yield $(\mathrm{kg} / \mathrm{ha})$ in pearl millet

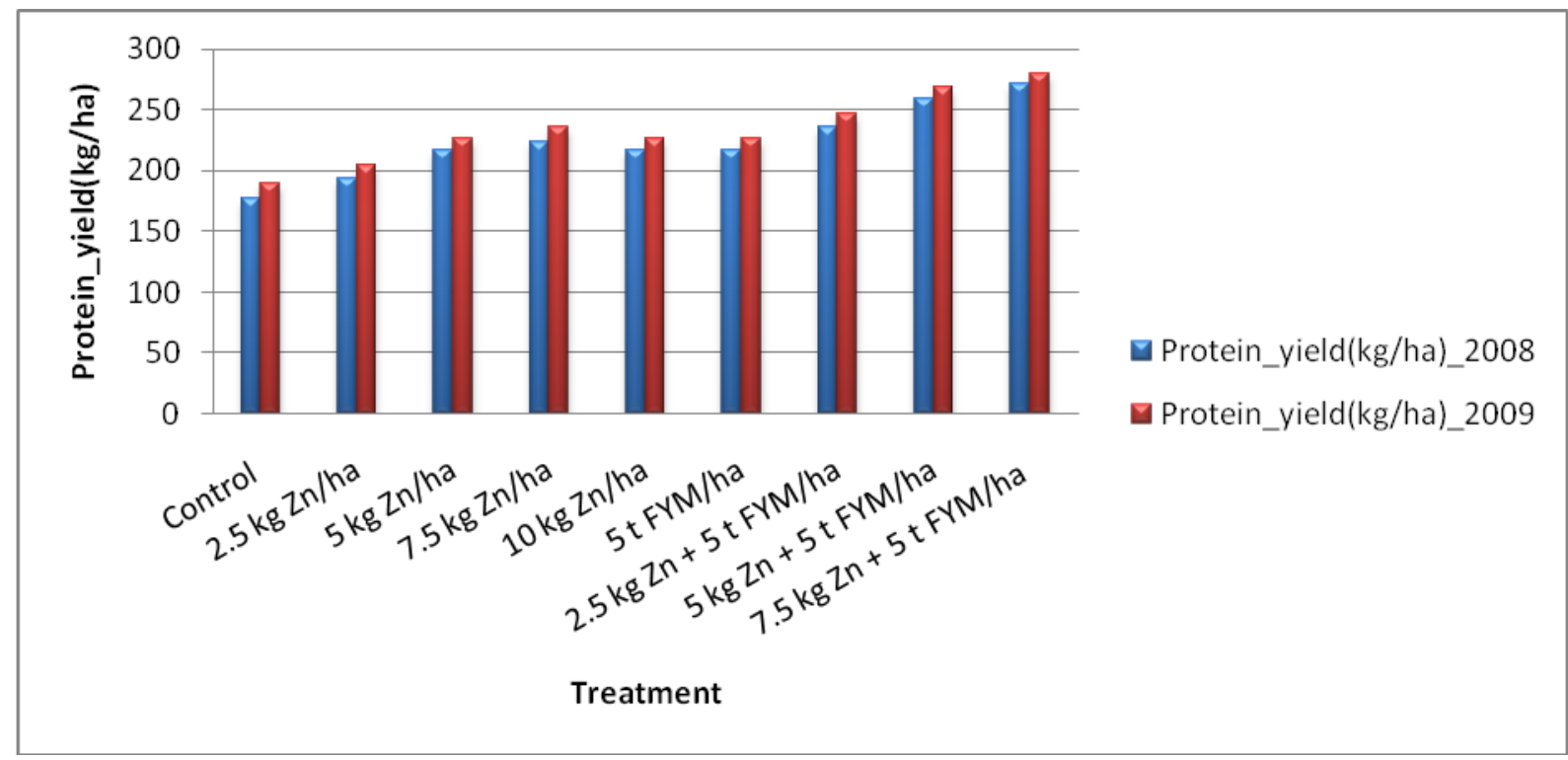

The $\mathrm{Zn}$ uptake by grain increased from 35.8 to $63.1 \mathrm{~g} / \mathrm{ha}$ and from 38.8 to $64.8 \mathrm{~g} / \mathrm{ha}$ with $7.5 \mathrm{~kg} \mathrm{Zn} / \mathrm{ha}$ during first and second year, respectively.

The corresponding increases by stover were from 203.9 to 315.8 and from 215.0 to 330.4 $\mathrm{g} / \mathrm{ha}$. Malewar et al., (2001) reported similar results. Application of $\mathrm{Zn}$ and FYM, either alone or in combination significantly increased the zinc uptake by the crop. The zinc along with FYM was more effective than zinc application alone. This suggests that besides adding zinc to soil, FYM also enhanced the efficiency of applied zinc and solubilizes native $\mathrm{Zn}$ to make it available for plants. Similar observation was also recorded by Singh et al., (1991, 1998, 2008). 


\section{Residual effect on wheat}

\section{Zinc}

A study of table 2 reveals that the zinc application in preceding crop increased the concentration of $\mathrm{Zn}$ in wheat grain and straw significantly over control. The zinc content in wheat grain during first and second year increased from 19.8 to $29.5 \mathrm{mg} / \mathrm{kg}$ and 20.2 to $30.0 \mathrm{mg} / \mathrm{kg}$ with $10 \mathrm{~kg} \mathrm{Zn} / \mathrm{ha}$, respectively. This increase in zinc content in plants may be ascribed to increased availability of zinc in soil on the addition of soluble $\mathrm{ZnSO}_{4}$. Dwivedi et al., (2002) also reported similar results. Application of $5 \mathrm{t} \mathrm{FYM/ha} \mathrm{in}$ preceding pearl millet crop improved the absorption of zinc by the crop over control. Al regards the combined effect of zinc and FYM, the increase in zinc concentration was significant in both crop seasons. The maximum values of zinc content in wheat grain and straw were recorded under $10 \mathrm{~kg}$ $\mathrm{Zn} / \mathrm{ha}$ and $5 \mathrm{t} \mathrm{FYM/ha}$ treatment in both the years of study (Singh et al., 2007, Gupta et al., 1987).

A further study of table 2 indicates that the application of zinc in preceding crop significantly increased the average zinc uptake by wheat grain from 90.2 to 146.5 $\mathrm{g} / \mathrm{ha}$. Each level of applied zinc had significantly beneficial effect on its uptake by wheat crop. This increase in $\mathrm{Zn}$ uptake with its addition may be ascribed to greater grain and straw production. Similar results were reported by Arya et al., (2000) and Dwivedi et al., (2002). The residual effect of FYM on zinc uptake by wheat grain and straw was significant over control in both crop seasons. The maximum values of zinc uptake by wheat grain and straw were recorded under $10 \mathrm{~kg}$ $\mathrm{Zn} / \mathrm{ha}$ and $5 \mathrm{t} \mathrm{FYM/ha} \mathrm{treatment} \mathrm{in} \mathrm{both} \mathrm{crop}$ seasons. The results, thus, indicate the beneficial effect of combined used of $\mathrm{Zn}$ levels with FYM.
The emergence of zinc deficiency is largely attributed to nutrient imbalance induced by depletion of soil fertility as result of intensive cultivation of high yielding varieties of cop plants, increased use of high analysis fertilizes and decreased recycling of crop residues and animal wastes. The content and yield of protein in Perl millet grain over controlled increased significantly with zinc application in both the cop seasons and maximum values were recoded under 10 and $7.5 \mathrm{~kg}$ zinc per hectare respectively. Conjoint use of FYM and Zinc was found more beneficial in improving the percentage as well as yield of protein in pearl millet crop.

\section{References}

Arya, K. C., and Singh S. N. 2000. Effect of different levels of phosphorus and zinc on yield on nutrients uptake of maize with and without irrigation. Indian $\mathrm{J}$ of Agron 45; (4); 717-721

Dahiya, S.S., Goel Sunil, Antil R. S. and Karwaora S.P.S. 1987. Effect of farm yard manure and calcium on dry matter yield and nutrients uptake by maize. J of Indian society and soil sciences. 35-; 454-460.

Dwivedi, S.K., Singh R. S. and Dwivedi K. N. 2002. Effect of sulphur and nutrition and quality of maize in typic ustocrept soil of Kanpur. Indian $\mathrm{J}$ of Soil sciences. 50(1); 70-74

Gangwar, and Singh 1988. Effect of Zinc application of yield and quality of lentil (Lens esculata medic) Legumes Reseach Res (1); 11-14

Gupta, V. K., and Hans Raj 1987. Response of zinc to some cop growth in loamy sand soil of Haryana. Agri. Sci. Digest, 7; 101-103

Lindsay, W. L., and Norvell W. A. 1978. Development of a DTPA soil test for zinc, $\mathrm{Fe}, \mathrm{Mn}$, and $\mathrm{Cu}$. Soil science Soc Am. J., 42; 421-428. 
Melawar, G. U., Kate, S. D. Walikar, S. L. and Syed, Ismail 2001. Inteaction effects of zinc and been boron on yield nutrient uptake and quality of mustard (Brassica juncea) on A typic Haplustert J. Indian society of soil science 49(4) 763-765

Sharma, B.D., and Singh SP, 1990. Critical zinc level in relation to growth and development winter maize in aridisols. J. Indian society of soil science $38(1)$; 89-92

Singh, A. P., Sakal R. Sinha R B and Bhoghal N S 1998. Use efficiency of applied zinc alone and mixed with biogas slurry in rice - wheat cropping system Indian society and soil sciences. 46; 75-80

Singh, D., and Mandeep Kaur. 2004. Response of wheat to zinc application in different soil of semi-arid region Indian society of soil science 33(4); 821-835

Singh, M., and Yadav, B.L. 2007. Effect of organic materials and zinc on yield of wheat and soil properties under higher RSC water. Ann. PI. Soil Res. 9(1): 4749

Singh, V., and Tomar, J.S. 1991. Effect of K and FYM levels on yield and uptake of nutrients by wheat. Potassium Res. 7 (4): 309-313.

Singh, V., Singh S. Singh J 2008. Direct and Residual effect of zinc on yield and its uptake in ice heat cropping system Annual plant soil research 10(1); 48-51

Singh, Y.P., and Singh, Vinay 1998. Response of nitrogen and zinc levels on biomass quality and chemical composition of forage crop. Forage Research, 24(1). 21-23.

Subbiah, B.V., and Asija, G.L. 1956. A rapid procedure for the estimation of available nitrogen in soils. Curr. Sci. 25: 259-260.

Tiwari, K.N., Dwivedi, B.S. Tiwari, A. Dagur, B.S., and Sharma, H.L. 1995. Status of $\mathrm{S}, \mathrm{Zn}, \mathrm{Fe}, \mathrm{Cu}$ and $\mathrm{Mn}$ in soil and plants and delineation of the areas of their deficiencies in central southeastern and Bundelkhand zones of Uttar Pradesh.Fertil. News 10 (7): 19-34.

Verma, S. S., Singh Navneet Joshi Y P. and Deorari Vijay. 2005. Effect of nitrogen and zinc on growth characters, herbage yield and nutrient uptake and quality of fodder sorghum. Indian $\mathrm{j}$ of Agron 50(2); 167-169

\section{How to cite this article:}

Anand Pathak, Apoorv Tiwari, Akhil Gupta and Vipin Kumar. 2017. Measurement of Effectiveness of Zinc with and without FYM on Protein Production by Pearl Millet-Wheat Sequence. Int.J.Curr.Microbiol.App.Sci. 6(9): 2670-2678.

doi: https://doi.org/10.20546/ijcmas.2017.609.329 